\title{
Antibacterial Properties of Marine Sponges from Mauritius Waters
}

\author{
J Govinden-Soulange ${ }^{1^{*}}$, D Marie ${ }^{2}$, S Kauroo ${ }^{1}$, R Beesoo ${ }^{1}$, A Ramanjooloo ${ }^{2}$ \\ ${ }^{1}$ Faculty of Agriculture, University of Mauritius, Reduit, ${ }^{2}$ Mauritius Oceanography Institute, Quatre Bornes, Mauritius
}

*For correspondence: Email: joyces@uom.ac.mu; Tel: +2304037692; Fax: +2304655743

\begin{abstract}
Purpose: To investigate the antimicrobial activity of crude and fractionated extracts of Biemna tubulosa and Stylissa spp. thriving in Trou aux Biches lagoon, North East Mauritius.

Methods: Crude extracts (methanol: dichloromethane 1:1) and fractions of Biemna tubulosa and Stylissa spp (hexane, ethyl acetate and butanol) were tested against some bacterial organisms, namely, Escherichia coli, Staphylococcus aureus and Enterococcus faecalis, using broth microdilution assay. The extracts were screened for the presence of compounds that could be responsible for bioactivity.

Results: Preliminary chemical screening revealed the presence of tannins, saponins, terpenes, alkaloids and phenols. The hexane fraction of Stylissa spp. and the ethyl actetate and butanol extracts of Biemna tubulosa were more active than the control antibiotic. Maximum antimicrobial activity was noted for the butanol fraction of Biemna tubulosa with minimum inhibitory concentration (MIC) of 0.091 $\mathrm{mg} / \mathrm{ml}$ against $\mathrm{E}$. coli. The hexane soluble fraction of Stylissa spp. was more active with MIC of 0.125 $\mathrm{mg} / \mathrm{ml}$ against $S$. aureus and E. coli and $0.250 \mathrm{mg} / \mathrm{ml}$ against $E$. faecalis.

Conclusion: The broad spectrum antibacterial activity of these sponges seemed to be due to the presence of sesterterpenes and triterpenes, alkaloids and tannins detected in the extract fractions. This is probably the first report on the antimicrobial activity of Biemna tubulosa and Stylissa spp. from Mauritius waters.
\end{abstract}

Keywords: Biemna tubulosa, Stylissa spp., Antibacterial activity, Marine sponges, MIC.

Tropical Journal of Pharmaceutical Research is indexed by Science Citation Index (SciSearch), Scopus, International Pharmaceutical Abstract, Chemical Abstracts, Embase, Index Copernicus, EBSCO, African Index Medicus, JournalSeek, Journal Citation Reports/Science Edition, Directory of Open Access Journals (DOAJ), African Journal Online, Bioline International, Open-J-Gate and Pharmacy Abstracts

\section{INTRODUCTION}

In the search for novel molecules to cure ailments, terrestrial biological resources have been greatly explored thus encouraging scientists to search for new bioactive molecules from the inner space of oceans which covers about $70 \%$ of the earth surface. Alterations in the marine environment have forced marine organisms to produce secondary metabolites to overcome these obstacles [1].
Bioactive substances from sponges or associated microorganisms have shown broad spectrum properties such as anticancer, antibacterial, antifungal, antiviral, antiprotozoal, anthelmintic, anti-inflammatory including manoalide (Luffariella variabilis) which is commercially available, immunosuppressive, neurosuppressive and antifouling [2]. The chemical diversity of sponge substances is remarkable, comprising Halichondrin B (Halichondria okadai) which is a new preclinical anticancer agent, Spongistatin 1 (Hyrtios erecta) and Aurantosides (Siliquariaspongia japonica and Homophymia conferta) [3]. Capon et al [4] 
attributed the antibiotic property of Spongia sp. to its sesterpene content.

To date, more than 5,000 different compounds have been isolated from about 500 species of sponges [5]. Mauritius is a small island found in the Indian Ocean with an area of $1865 \mathrm{~km}^{2}$, possessing an Exclusive Economic Zone of about $1.9 \mathrm{~km}^{2}$, which has not been fully exploited [6]. Except for the work of Wah et al [6], reports on the antimicrobial activities of sponges from Mauritius seawaters are scanty. We report in this paper the antimicrobial screening of crude extracts and fractions from two least studied sponge species, namely Biemna tubulosa and Stylissa spp, collected from Mauritian waters and tested on three human pathogen bacterial strains, namely, Escherichia coli, Staphylococcus aureus and Enterococcus faecalis, using standard broth microdilution methods.

\section{EXPERIMENTAL}

\section{Sponge collection and identification}

The two species were collected in March 2010 (water temperature, $24 \pm 1{ }^{\circ} \mathrm{C}$ ) at depths varying from 10 - 22 metres on the coastline of Trou aux Biches (around the north and the east part of Mauritius Island) by Scuba diving. Biemna tubulosa is a greenish brown encrusting sponge specimen with protuberances of $10-15 \mathrm{~cm}$, mostly found on dead coral surfaces. The oscules, but not the ostioles, are visible and the sponge is very soft to the touch. Biemna tubulosa releases colourless mucus which irritates the skin when cut. Stylissa sp. is an encrusting sponge, reddish brown specimen forming a layer of 2-3 cm thick on dead coral surfaces. The sponge is delicate and soft at the touch and can easily be removed from the substrate. A voucher specimen of each sponge tissue was deposited at the herbarium of the University of Amsterdam in the Netherlands for identification by Dr Van Soest, Head Curator of the Zoology Museum. Biemna tubulosa was given voucher number ZMAPOR 18313 and Stylissa,spp. ZMAPOR 18331 for further reference. The freshly collected sponges were cleaned and stored at $-70{ }^{\circ} \mathrm{C}$ prior to lyophilisation and extraction.

\section{Extraction}

Freeze-dried samples of Stylissa sp (100 g) and Biemna tubulosa (100.28 g) were extracted with dichloromethane: methanol: (DCM:MeOH) (1:1 $\mathrm{v} / \mathrm{v}$ ) during $96 \mathrm{~h}$ and the filtrate (crude extract) was concentrated under vacuum at a maximum temperature of $40{ }^{\circ} \mathrm{C}$. Thereafter, $100 \mathrm{ml}$ of distilled water was added to each extract and each solution was then partitioned with hexane $(6 \times 200 \mathrm{ml})$ to afford the hexane fraction. The aqueous extracts were then successively partitioned with ethyl acetate $(5 \times 200 \mathrm{ml})$ affording the ethyl acetate soluble fraction. The ethyl acetate fraction was concentrated under vacuum. Similarly, a butanol fraction was obtained by partitioning the aqueous extract with butanol (4 x $200 \mathrm{ml})$. Methanol was added to the concentrated butan-1-ol extract in order to remove remaining sea salt present in the extract and the final extract was concentrated under vacuum.

\section{Phytochemical screening}

Chemical screening was effected using qualitative tests including thin layer chromatography as per Harborne et al [7]. The crude extract, hexane, ethyl acetate and butanol fractions were each resuspended in $30 \mathrm{~mL}$ of methanol $(\mathrm{MeOH})$ prior to investigation.

\section{Test for anthraquinones}

Each extract $(1 \mathrm{ml})$ was dissolved in warm distilled water and the solution was filtered. After extraction with, benzene, 5 drops of ammonia solution was added to the filtrate and the solution was shaken. A red colouration in the lower aqueous layer was taken as a positive test for anthraquinones.

\section{Test for coumarins}

Concentrated ammonia solution (4 drops) was added to $1 \mathrm{ml}$ of each extract. A smear of this solution was viewed under long wave (366 nm) UV to detect a green fluorescence.

\section{Test for leucoanthocyanins and flavonols}

Each extract $(1 \mathrm{ml})$ was washed with petroleum ether. To the washed material, ethanol was added and the solution was filtered. Aliquots of the filtrate were placed in two test tubes. Concentrated $\mathrm{HCl}$ was added to both test tubes. To one of the tubes, magnesium turnings was added. The other tube was placed in hot water bath. After $30 \mathrm{~min}$, a red colour was taken as positive.

\section{Test for saponins}

Freeze dried sponge material $(0.5 \mathrm{~g})$ was treated with water for 5 minutes at $100^{\circ} \mathrm{C}$ in a test tube. The test tube was allowed to cool and shaken vigorously. Formation of persistent froth (1 - 2 $\mathrm{ml}$ ) was considered positive for saponins. 
Test for tannins

Each extract $(1 \mathrm{ml})$ was washed with petroleum ether and the solution was filtered. To a portion of the filtrate an equal amount of freshly prepared $3 \%$ ferric chloride and potassium hexacyanoferrate (III) was added drop wise. A blue precipitate indicated the presence of hydrolysable tannins and a green precipitate for condensed tannins.

\section{Thin-layer chromatography (TLC) analysis}

Alkaloids, phenols and terpenes were detected using the following mobile phases of different polarities Ether: Methanol: Acetone (9:2:8:1) v/v for alkaloids; chloroform: methanol $(7: 3 \mathrm{v} / \mathrm{v})$ for phenols; dichloromethane: methanol $(9: 1 \mathrm{v} / \mathrm{v})$ for steroids/terpenes. The chromatograms were visualized under UV light $(366 \mathrm{~nm})$. Alkaloids were identified as orange-brown spots after spraying with Dragendorff's reagent. Blue spots on the chromatogram after spraying with FolinCiocalteu reagent confirmed the presence of phenols and greenish blue spots validated the presence of terpenes.

\section{Antimicrobial assay}

The serial dilution technique described by Eloff [8] was used to determine the minimum inhibitory concentration (MIC) for antibacterial activity of crude and fractionated extracts. Two $\mathrm{ml}$ cultures of three bacterial strains, Escherichia coli (ATCC 25922), Staphylococcus aureus (ATCC 25313), Enterococcus faecalis (ATCC 29212), were prepared and incubated overnight for 16-18h at $37{ }^{\circ} \mathrm{C}$. The overnight cultures were diluted with sterile $\mathrm{MH}$ (Mueller-Hinton) broth (1ml bacteria/100ml $\mathrm{MH}$ ) in order to get absorbance of 0.4-0.6 at $600 \mathrm{~nm}$ At this absorbance, E. coli culture had a concentration of $0.4 \times 10^{9} \mathrm{CFU} / \mathrm{ml}$, S.aureus had a concentration of $0.8 \times 10^{9}$ $\mathrm{CFU} / \mathrm{ml}$ and $E$. faecalis had a concentration of $0.1 \times 10^{9} \mathrm{CFU} / \mathrm{ml}$. For each of the bacteria used, $100 \mu \mathrm{l}$ of each extract was two-fold serially diluted with $100 \mu \mathrm{l}$ sterile distilled water in a sterile 96-well micro-plate. A similar two-fold serial dilution of aqueous chloramphenicol solution (Sigma, $0.01 \mathrm{mg} / \mathrm{ml}$ ) was used as positive control against each bacterium. Methanol was used as negative control. A hundred microliters of bacterial culture was added to each well. The microplates were covered, sealed and incubated overnight at 37 ${ }^{\circ} \mathrm{C}$ for $24 \mathrm{~h}$. Bacterial growth was tested with the addition of $50 \mu \mathrm{l}$ of $0.2 \mathrm{mg} / \mathrm{ml} p$ iodonitrotetrazolium violet (INT) to each well. Bacterial growth in the wells was indicated by a red colour after incubation at $37^{\circ} \mathrm{C}$ for $30 \mathrm{~min}$ and clear wells indicated inhibition by the tested samples [8].

\section{Statistical analysis}

The variation between the minimum inhibitory concentrations of the different sponge extracts against the test bacterial strains was analysed by two-factor ANOVA with 3 replicates using Microsoft Excel 2007. The data were analysed at $95 \%$ level of significance.

\section{RESULTS}

\section{Yield of extracts}

The total yield of the crude extract was relatively low $19.11 \%$ w/w for Styllissa spp and $9.66 \%$ for Biemna tubulosa. The yield for the fractions of Stylissa spp and Biemna tubulosa were highest for the butanol fraction (2.76\%) for Stylissa spp and hexane fraction $(2.41 \%)$ for Biemna tubulosa.

\section{Phytochemical profile of the sponges}

The secondary metabolites identified in both marine sponges appear to be similar (Table 1). Tannins (hydrolysable and condensed tannins), phenol, alkaloids, steroids and saponins were detected. However, saponin content of Stylissa spp appeared higher as compared to that of Biemna tubulosa, where only trace amount was detected as indicated by some frothing in Styllissa extracts. . On the other hand, Stylissa spp extracts recorded the presence of condensed tannins only, whereas Biemna tubulosa extracts revealed the presence of both condensed and hydrolysable tannins. Moreover, thin layer chromatographic (TLC) analysis on silica gel of the different extracts showed the presence of strong levels of alkaloids and phenols in both marine sponges. Nevertheless, steroids/terpenoids were detected in the crude extract and the hexane and ethanol fractions of Biemna tubulosa and only in hexane and ethanol fractions of Stylissa spp.

\section{Antibacterial testing}

The MIC values of the extracts of Biemna tubulosa and Stylissa spp. using the microdilution assay are indicated in Table 2. The results demonstrate that all eight extracts of both marine sponges exhibited varying degrees of activity against the test bacterial species. The extracts also appeared to be broad spectrum as their activities were independent on the Gram reaction. It was also generally observed that fractions had more potent antimicrobial action. 
Table 1: Compounds detected in crude and fractionated extracts of Biemna tubulosa and Styllissa spp. from Mauritius waters

\begin{tabular}{|c|c|c|c|c|c|c|c|c|}
\hline \multirow[t]{2}{*}{ Class } & \multicolumn{4}{|c|}{ Biemna tubulosa } & \multicolumn{4}{|c|}{ Stylissa spp. } \\
\hline & C & H & $\mathbf{E}$ & B & C & H & $\mathbf{E}$ & B \\
\hline Coumarins & - & - & - & - & - & - & - & - \\
\hline Tannins & + & - & + & + & + & + & + & + \\
\hline Saponins & + & $\mathrm{N}$ & $\mathrm{N}$ & $\mathrm{N}$ & + & $\mathrm{N}$ & $\mathrm{N}$ & $N$ \\
\hline Anthraquinones & - & - & - & - & - & - & - & - \\
\hline Leucoanthcyanins & - & - & - & - & - & - & - & - \\
\hline Flavonols & - & - & - & - & - & - & - & - \\
\hline Steroids/Terpenes & + & + & + & - & - & + & + & - \\
\hline Alkaloids & - & + & + & + & + & + & + & + \\
\hline Phenols & - & - & + & + & - & - & + & + \\
\hline
\end{tabular}

$C=$ crude extract, $H=$ hexane soluble fraction, $E=$ ethyl acetate soluble fraction, $B=$ butan-1-ol soluble fraction; $N=$ not evaluated

Table 2: Antibacterial activity of crude and fractionated extract of Biemna tubulosa and Stylissa spp (mg/ml)

\begin{tabular}{|c|c|c|c|c|c|c|c|c|c|}
\hline \multirow[t]{2}{*}{ Test organism } & \multicolumn{4}{|c|}{ Biemna tubulosa } & \multicolumn{2}{|c|}{ Stylissa spp } & \multicolumn{3}{|r|}{ Chloramphenicol } \\
\hline & $C$ & $H$ & $E$ & $B$ & $C$ & $H$ & $E$ & $B$ & \\
\hline $\begin{array}{l}\text { E. coli } \\
\text { (ATCC 25922) }\end{array}$ & 2.18 & $0.763^{\dagger}$ & 0.111 & $0.091^{\mathrm{e}}$ & 2.55 & 0.125 & 1.14 & 1.81 & $0.625^{\dagger}$ \\
\hline $\begin{array}{l}\text { S. aureus } \\
\text { (ATCC 25313) }\end{array}$ & $2.18^{\mathrm{a}}$ & $1.53^{\mathrm{a}}$ & $0.223^{\mathrm{C}}$ & $0.181^{\mathrm{c}}$ & $2.55^{\mathrm{x}}$ & $0.125^{z}$ & $1.14^{w}$ & $1.81^{w x}$ & $0.313^{d}$ \\
\hline $\begin{array}{l}\text { E. faecalis } \\
\text { (ATCC 29212) }\end{array}$ & $4.36^{\mathrm{D}}$ & $3.05^{\mathrm{D}}$ & $0.223^{c}$ & $0.363^{a}$ & $5.09^{y}$ & $0.250^{\vee}$ & $2.28^{x}$ & $1.81^{w x}$ & $0.313^{a}$ \\
\hline
\end{tabular}

than crude extracts of both sponges against all bacteria tested. Interesting activity was noted with Biemna tubulosa butan-1-ol fractions and ethyl acetate fractions against Escherichia coli and Staphylococcus aureus. The anti bacterial activity of the butan-1-ol fraction was the highest against Escherichia coli at a concentration of $0.091 \mathrm{mg} / \mathrm{ml}$ followed by ethyl acetate fraction against Escherichia coli at a concentration of $0.111 \mathrm{mg} / \mathrm{ml}$. In the case of the sponge Stylissa spp, the lowest MIC values were recorded with hexane and ethyl acetate fractions against Escherichia coli and Staphylococcus aureus to the extent of $0.125 \mathrm{mg} / \mathrm{ml}$. In nine cases the MIC values of the extracts were better than the values for the positive control, chloramphenicol. The overall observation was that among the three bacterial organisms maximum growth suppression was noted against gram negative bacteria Escherichia coli followed by S.aureus and E.faecalis was the least sensitive in the assay. Generally, Biemna tubulosa extracts were more active than those of Stylissa spp. Wells containing methanol showed no colour change.

\section{DISCUSSION}

The crude extracts of both sponges demonstrated the highest values for minimum inhibitory concentration (MIC) in the range of 2.55-5.09 $\mathrm{mg} / \mathrm{ml}$ probably because crude extracts are generally a mixture of active and non active compounds and therefore higher MICs are expected. The MIC of crude extracts is rarely found to be $<0.1 \mathrm{mg} / \mathrm{ml}$ but with more refined fractions or solitary compounds, MICs of < $0.1 \mathrm{mg} / \mathrm{ml}$ may be suggestive of good antimicrobial activity and thus can be considered worthy for further investigations [9].

In an analysis by Kelman et al [10], the antibacterial activity of dichloromethane: methanol extract of the marine sponge Amphimedon viridis assessed against a panel of bacteria was found to be $>0.250 \mathrm{mg} / \mathrm{ml}$ against all the bacterial isolates. The antibacterial effects of fractions of Biemna stylissa spp. exhibited broad spectrum antibacterial activity and inhibited the growth of all the tested bacteria. Among the pathogens tested, the Gram negative E. coli and the Gram positive $S$. aureus exhibited maximum sensitivity whereas $E$. faecalis showed the least sensitivity. It is equally interesting to note that the Gram positive $S$. aureus was also susceptible to the sponge extracts. This finding is significant because multi-drug resistant strains of the organism are on the increase in both hospital and community environments against orthodox antibiotics and its control is very difficult by therapeutic means.

Besides, the hexane fraction of Stylissa was the most promising extract, showing activity against all three bacterial isolates with the lowest MIC of $0.125 \mathrm{mg} / \mathrm{ml}$ against $E$. coli and $S$. aureus. In the present study, a 20 fold increase in bioactivity of 
Stylissa was recorded in the hexane fraction against E.coli and S.aureus as compared with MIC values of their respective crude extracts. This suggests that the more bioactive components of the Stylissa extract could probably be among the non polar compounds as peak antibacterial activity (lowest $\mathrm{MIC}=0.125$ $\mathrm{mg} / \mathrm{ml}$ ) had been recorded by the hexane extract. Besides, chemical screening of the hexane fractions of both sponges Biemna tubulosa and Stylissa spp. revealed the presence of terpenes which are renowned for their antibacterial properties. Marine sponges have been shown to contain sesterterpenes and triterpenes which are reported to be antibacterial $[11,12]$.

The bioactivity of sesterterpenes in marine sponges could be due to their ability to undergo non-bonded interactions with phospholipidase thereby providing substrates for pro-inflammatory mediators [13]. Although there are no previous studies that have been published on bacterial growth inhibition by Stylissa spp from Mauritius waters, other marine sponges of the genus Stylissa, have been reported as demonstrating significant level of antibacterial activity. Stylisin 2, a natural cyclic heptapeptide isolated from the Jamaican sponge Stylissa caribica exhibited strong antibacterial activity against two Grampositive bacteria $B$. subtilis and $S$. aureus and two Gram-negative bacteria Pseudomonas aeruginosa and Klebsiella pneumoniae with MIC values of $0.0125-0.006 \mathrm{mg} / \mathrm{ml}$ [14].

The more polar extracts of Biemna tubulosa seemed to be more bioactive than the non polar extract against the tested bacteria. More potent bioactivity was noted against $E$. coli. This activity seemed to be due to the presence of tannins which were identified only in the ethyl acetate and butanol fractions Biemna spp. Tannins, being a member of the phenolic compounds, have also been found to inhibit extracellular microbial enzymes, and to act on microbial metabolism through inhibition of oxidative phosphorylation and protein synthesis [15]. Marine sponges of the genus Biemna have been described to generate a broad spectrum of metabolites including steroids, alkaloids and some of them exhibited cytotoxic activities. Likewise neuronal differentiation inducing compounds (pyridoacridine alkaloids) were isolated from the marine sponge Biemna fortis which demonstrated activity against a murine neuroblastoma cell line [16]. Sponges have developed an amazingly efficient immune system, which is reminiscent of that found in invertebrates. Nowadays, people prefer to use remedies of natural origin for curing illnesses as these are claimed to produce less side effects.
The antibacterial activity of the marine sponges Biemna tubulosa and Stylissa spp, are being reported for the first time. This study has demonstrated that the two marine sponges collected from Mauritian water possess strong antibacterial potential. The results showed that all the 4 extracts (crude, hexane, ethyl acetate and butanol) of each marine sponge exhibited broad antibacterial activity. These findings therefore confirm the hypothesis that these marine sponges can be further studied as interesting sources for new antibacterial agents with better activity. The fact that the most nonpolar extracts of Biemna tubulosa and polar extracts of Stylissa spp had higher antimicrobial activity than the reference antibiotic, chloramphenicol, is noteworthy. It seems important to recommend that further studies using isolated purified constituents be done in a bid to produce a drug with a fixed dosage of administration. Toxicological studies are also necessary in order to determine the safety of such a drug in humans.

\section{CONCLUSION}

The broad spectrum antibacterial activity of these sponges seemed to be due to the presence of terpenes, alkaloids and tannins detected in the bioactive fractions. This work confirms the hypothesis on the chemical richness of sponges and is the first report on the antimicrobial activity of Biemna tubulosa and Stylissa spp from Mauritius waters, to the best of our knowledge.

\section{ACKNOWLEDGEMENT}

The authors are thankful to Dr Van Soest, Head Curator of the Zoology Museum, University of Amsterdam, the Netherlands, for the identification of the sponges.

\section{REFERENCES}

1. Jirge S, Chaudhar Y. Marine: the ultimate source of bioactive and drug metabolites. Int $J$ Res Ayurveda \& Pharmacy 2010; 1: 55-62.

2. Laport MS, Santos OCS, Muricy, G. Marine sponges: Potential sources of new antimicrobial drugs. Curr Pharmaceutical Biotechnol 2009; 10: 86-105.

3. Song $X$, Zhang $H T, W u C P$, Zhang $W$, Yuan Q. Study on the bioactivity of extracts form marine sponges in Chinese sea. J Exp Mar Biol Ecol 2004; 298: 7178.

4. Capon RJ, Groves DR, Urban S, Watson RG. Spongiaquinone Revisited:Structural and stereochemical studies on marine sesquiterpene/quinones from a southern Australian marine sponge, Spongia sp. Aust J Chem 1993; 46: 1245-1253.

5. Rifai S, Fassouane A, El-Abbouyi A, Wardani A, Kijjoa $A$, Van Soest $R$. Screening of antimicrobial activity of marine sponge extracts. Journal de Mycologie Médicale 2005; 15: 33-38.

Trop J Pharm Res, February 2014; 13(2): 253 
6. Li Kam Wah, H, Jhaumeer-Laulloo S, Choong Kwet Yive $R$, Bonnard I, Banaigs B, Marie D. Biological and chemical study of some soft corals and sponges collected in Mauritian waters. Western Indian Ocean J Mar Sci 2006; 2: 115-121.

7. Harborne JB, Mabry TJ, Mabry H. The Flavonoids. Chapman and Hall, London, 1975; pp 168-175.

8. Eloff JN. A sensitive and quick microplate method to determine the minimum inhibitory concentration of plant extracts for bacteria. Planta Med 1998; 64: 711-713

9. Webster D, Taschereau P, Belland RJ, Sand C, Rennie $R P$. Antifungal activity of medicinal plant extracts; preliminary screening studies. I Ethnopharmacol 2007: 115: 140-146.

10. Kelman D, Kashman $Y$, Rosenberg E, Ilan M, Ifrach I, Laya Y. Antimicrobial activity of the reef sponge Amphimedon viridis from the Red sea: evidence for selective toxicity. Aqua Microbial Ecol 2001; 24: 916.

11. Ebada SS, Lin WH, Proksch $P$. Bioactive sesquiterpenes and triterpenes from marine sponges .Occurrence and pharmacological significance. Mar Drugs 2010; 8: 313-346.

12. Grode SH, Cardelina JH. Sesquiterpenes from the sponge Dysidea etheria and the nudibranch Hypseludoris zebra. J Nat Prod 1984; 47(1): pp.76.

13. Glaser KB, De Carvalho MS, Keman MR, Faulkner DJ. Structure activity studies and definition of the pharmacophore for phospholipase A2 inactivation. Mol Pharmacol 1989; 35(5): 782-788.

14. Dahiya R, Gautam H. Total synthesis and antimicrobial activity of a natural cycloheptapeptide of marine origin. Mar Drugs 2010; 8: 2384-2394.

15. Scalbert A. Antimicrobial properties of tannins. Phytochem 1991; 30(12); 3875-3883.

16. Aoki S, Wei H, Matsui K, Rachmat R, Kobayashi $M$. Pyridoacridine Alkaloids inducing Neuronal Differentiation in a neuroblastoma cell line from marine sponge Biemna fortis. Bio-organic and Med Chem 2003; 11: 1969-1973. 